\title{
Sustainability assessment in the built environment of Lake Mariout, Alexandria city, Egypt: factors and a decision framework
}

\author{
A. Nayer ${ }^{1,2} \&$ M. M. Abouhassan ${ }^{1}$ \\ ${ }^{1}$ Architecture Department, College of Architecture and Design, \\ Effat University, Saudi Arabia \\ ${ }^{2}$ Department of Architectural Engineering, BHI, \\ Ministry of Higher Education, Egypt
}

\begin{abstract}
Considered to be a major strategic imperative of Alexandria City, Lake Mariout is heavily polluted and suffers from eutrophication due to discharges from drains carrying industrial and municipal waste leading to destruction of fish species. The current status is decreased quality, limited non-commercial food source to local residents. As a result, the lake would need large quantities of freshwater inflow to recover its ecology, the consensus is that this lake will continue the salinization process and eventually lose most of its natural resources.

The research presents an assessment of the built environment that surrounds Lake Mariout in terms of economic importance, environmental impacts to enable further sustainable prospects of future development.

The primary objectives of this paper is to highlight the main problems, exposed to the region of Lake Mariout and provides an overall analysis of sustainability aspects for the region. The results will be presented within a holistic approach for urban and economic development plan including environmental protection for the biosphere region. Therefore, an environmental impact assessment will contribute to rearticulating human behavior and activities relevant to adopted strategies for sustainable development.

Keywords: sustainability assessment, built environment, sustainable development, Lake Mariout, environmental impacts.
\end{abstract}




\section{Introduction}

Sustainability is a holistic concept with a world-wide scale of reference. The concept of sustainable development has received recognition by the international communities through a number of international forums and reports since the late eighties; especially on the Built Environment Forms of Adaptation.

Scientific and technological progress contributed greatly to the development of environmental conservation and reducing pollution and preserving resources, due to the tremendous advancement achieved by means of technology in these areas. However, we cannot provide the protection for the environment without rules and binding controls to ensure such protection that obliges individuals and communities to avoid environmentally harmful acts and commitment to behavior that preserves and protects its resources and ensure its safety.

\section{Methodological approach}

The research paper investigates the sustainability of the built environment of Lake Mariout, Alexandria city, Egypt. Therefore it is very important to consider both aspects of the natural environment, the physical and cultural built environment. This will help to facilitate the assessment and application of long term sustainable development strategy for the Lake Mariout region in order to provide a decision framework for evaluation of urban planning and design. A contextual perception of what living entities exists in lake water and what is the resident's experience of the lake, the valley around the lake, the fishermen and workers socio-economic activities linked to the province and its surroundings Mariout urban environment.

\subsection{Problem definition}

As a result of progressive advancements in technology which pollutes the environment of the Lake Mariout area and a lack of continuous application of sustainability concepts in projects: "meeting the needs of the present generation without compromising the ability of future generation to meet their own needs".

The framework of the adopted assessment implies the most recognized principles of sustainable development which are:

- To consider, in an integrated way, the wider economic, social and environmental implications of our decisions and actions;

- To plan for a long-term rather than a short-term view when taking decisions and actions.

- To provide information for all citizens and the opportunity for them to participate in decision-making processes.

\subsection{The goal of the research}

One of the aims of this research is to overcome the above limitations by developing a framework which integrates the assessment of the natural resources, socioeconomic and the cultural aspects of the built environment at a district/zone level. 
This research also aims to develop conclusions for substantiated decision making processes for the built environment development of the Lake Mariout area. In the context of measuring progress towards environmental sustainability [1], a geographical approach suggests the need to profile existing infrastructure based on survey methods undertaken at the micro-scale, for example at the level of individual accommodation facilities, with results then aggregated to allow generalizations and comparisons to be made at larger geographical scales such as local, regional or national levels.

However mentioned that the lack of an integrated approach and implementable policy supporting the inclusion of ecological and social aspects in water management is prevalent [2]. Furthermore, the lack of an adaptive governance structure has exacerbated the process and intensified the decline. This requires the existence of a clear content and a conceptual framework or a theoretical guide that can help designers and decision makers to structure the problem of sustainability in the built environment.

\subsection{The research framework}

The first step is to regenerate the built environment, and its impacts in the long term including the history and geography of the territory Lake Mariout, boundaries expenditure, feeds and basins.

Secondly, the research should provide information on the socio-economic and environmental consequences of a development process through time; then integrate different evaluation approaches and scientific research which demonstrates the socio-economic and environmental changes and urban growth complexity. The final step is to consider the different viewpoints, objectives and interests of decision makers, stakeholders and citizens in a participation process.

Therefore, merging complex relationships between the different factors and functions of the built environment will contribute in the decision making of future developments in terms of environmental sustainability.

\section{Built environment description}

Mariout is the name given to the area extending west of the city of Alexandria, and the name Mariout is derived from the word Mariotes - a Greek word.

Lake Mariout is one of the four lagoons in Egypt: Lake Manzala, Mariout, Edco and Borollos, in the north of the delta. It is the smallest lake and the only lake that has no natural connections on the Mediterranean Sea. It is located south of the city of Alexandria and about 20 kilometers from the Mediterranean Sea. It is secluded body of salt water when creating Alexandria Lake stretched across its southern border [2].

The lake was connected to the south side of the River Nile and the northern side of the Mediterranean and during the nineteenth century and early twentieth century, parts of the lake became Salinas and turned to red due to the presence of chemicals. Other parts of the lake, especially the southern parts were areas for fishing. Lake Mariout is a shallow, closed lake which serves several important 
functions. Formally, fisheries production, water supply for irrigation, navigation, receiving body for industrial and domestic waste, and other human activities such as farming [3].
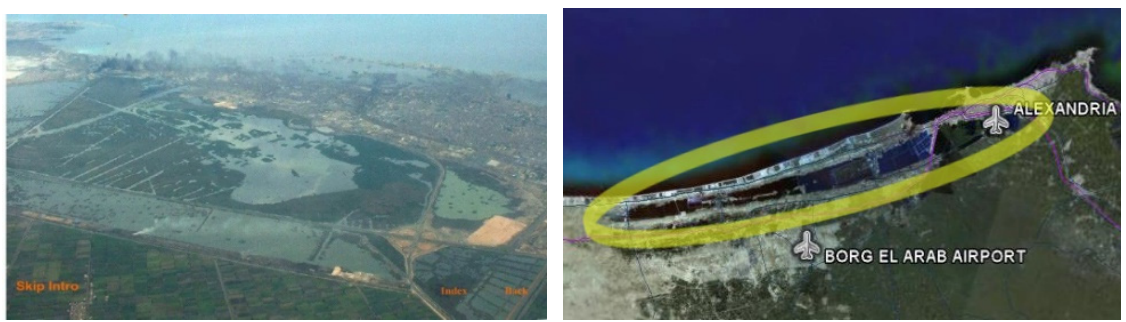

Figure 1: $\quad$ Satellite images describe the study area.

\subsection{Region and site topography}

The region extends to the north and north-west to the sea, and in the south-west to the outskirts of Valley Natrun. Lake Mariout stretches from the West to the seashore, land tight and fit for cultivation for a length of $60 \mathrm{~km}$ of the isthmus now known as Abu Sir, was called Old Taenia of Taposiris and extends from the "moon gate" Alexandria in the east to the west where it ends. Lake Mariout is the only water means to the west of Alexandria. The shores of Lake Mariout, filled with marine ports and villages and the fertile metropolitan center for the Metropolitan Area in particular, flourished in the Ptolemaic period [4].

\subsection{The history and geography of the territory Mariout}

Mariout region in which the Lake and the Valley of Mariout grew up due to geographic and environmental phenomenon for thousands of years. Table 1 shows the evolution of Mariout region for 35,000 years.
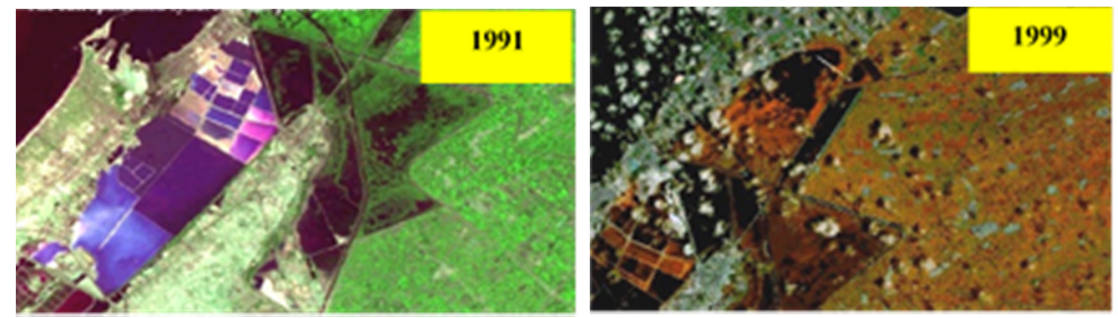

Figure 2: Old satellite images describe the history of the study area. 

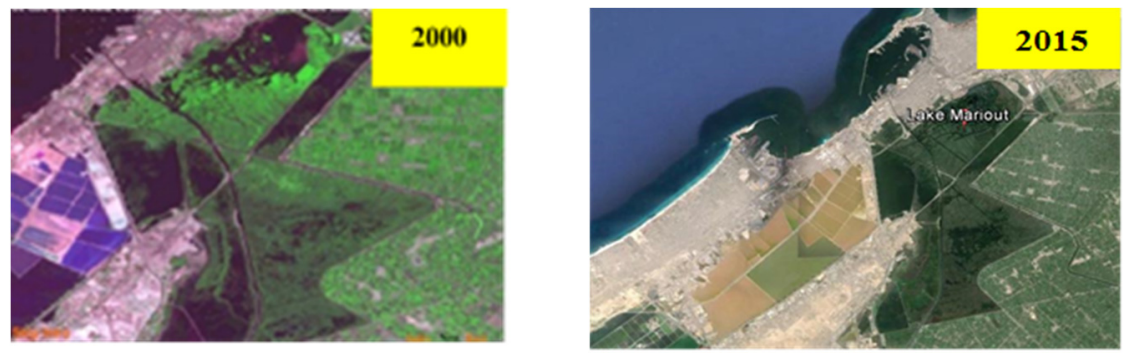

Figure 3: Satellite images describe the history of the study area.

Table 1: $\quad$ History of Mariout region [5].

\begin{tabular}{|c|c|}
\hline Years ago & History of Mariout region \\
\hline $\begin{array}{l}35000- \\
11000\end{array}$ & $\begin{array}{l}\text { - Mediterranean receded to nearly } 20 \text { kilometers in the north- } \\
\text { west direction. } \\
\text { - Left behind a significant low has entered the flood waters of } \\
\text { the Nile. }\end{array}$ \\
\hline $\begin{array}{l}8000- \\
11000\end{array}$ & $\begin{array}{l}\text { - Recession happened in the northeastern direction happened to } \\
\text { nearly } 10 \text { kilometers } \\
\text { - A rise in sea level will be increased significantly in the wake } \\
\text { of a major low is filled with water and water clusters formed } \\
\text { in the eastern part, which surrounds the south side of } \\
\text { Alexandria }\end{array}$ \\
\hline 6000 & $\begin{array}{l}\text { - Covered fresh water and salt most of the large low. } \\
\text { - It reached its borders to Hosh Issa area to the south and Kafr } \\
\text { El-Dawar. }\end{array}$ \\
\hline 2000 & $\begin{array}{l}\text { - It began canopic branch branches that were fueling fresh } \\
\text { water lake in decay. } \\
\text { - Canopic branch itself began to shrink and the gradual decline } \\
\text { until it reached to the point of almost complete disappearance } \\
\text { to the current border (Rashid) branch. }\end{array}$ \\
\hline 800 & $\begin{array}{l}\text { - Deposits accumulate as a result of a lack of supply of fresh } \\
\text { water lake began. } \\
\text { - The water level became lower. }\end{array}$ \\
\hline $\begin{array}{l}\text { Mohamed } \\
\text { Ali period }\end{array}$ & $\begin{array}{l}\text { - Mahmudiya channel was created. } \\
\text { - the city of Alexandria it became a city of great importance } \\
\text { economically and distinct center. }\end{array}$ \\
\hline
\end{tabular}




\subsection{Lake Mariout area}

The area of Lake Mariout is shown in Table 2.

Table 2: $\quad$ Area of Lake Mariout [6].

\begin{tabular}{|l|c|c|l|c|}
\hline Year & $\begin{array}{c}\text { Area } \\
\text { (thousand } \\
\text { acres) }\end{array}$ & $\begin{array}{c}\text { Area } \\
\left(\mathrm{Km}^{2}\right)\end{array}$ & \multicolumn{1}{|c|}{ Notes } & $\begin{array}{c}\text { Proportion } \\
\text { to the } \\
\text { original } \\
\text { area in } \\
1889\end{array}$ \\
\hline $\begin{array}{l}\mathbf{6 0 0 0} \\
\text { years } \\
\text { ago }\end{array}$ & 571315.66 & 2400 & $\begin{array}{l}\text { 80km along the northern coast } \\
\text { west of Alexandria and extending } \\
\text { south to 30 km. }\end{array}$ & - \\
\hline $\mathbf{1 8 8 9}$ & 60 & 252.0498 & $\begin{array}{l}\text { It became } 10.50 \% \text { of the total area } \\
\text { of the lake and the valley }\end{array}$ & - \\
\hline $\mathbf{1 9 2 0}$ & 41 & 172.234 & Shortage 31.67\% & $68.33 \%$ \\
\hline $\mathbf{1 9 5 2}$ & 38 & 159.632 & Shortage $7.32 \%$ & $63.33 \%$ \\
\hline $\mathbf{1 9 9 5}$ & 17 & 71.414 & Shortage $47.85 \%$ & $28.33 \%$ \\
\hline
\end{tabular}

\subsection{Lake Mariout division}

Lake Mariout is divided into four main basins and each area of the physical features and these basins are:

The main basin - basin of North West - Fishing basin - the south-western basin.
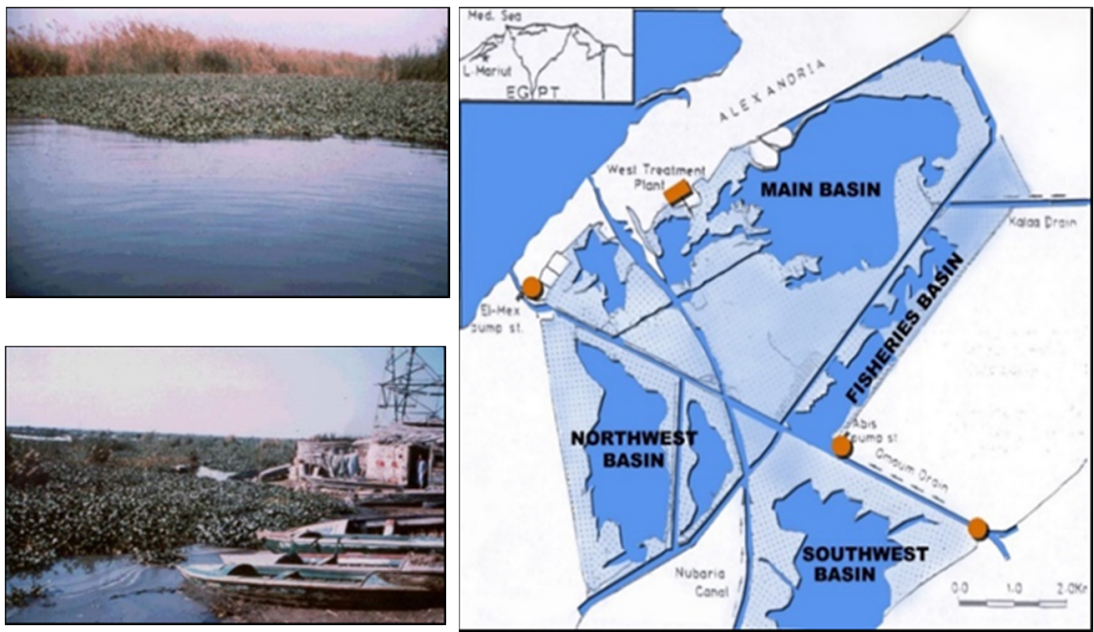

Figure 4: The basins of Lake Mariout. 
Table 3: The basins of Lake Mariout.

\begin{tabular}{|c|c|c|c|}
\hline Basin & $\begin{array}{c}\text { Area } \\
\text { (acres) }\end{array}$ & $\begin{array}{l}\text { The average depth of the } \\
\text { water basin (m) }\end{array}$ & Notes \\
\hline $\begin{array}{l}\text { 1. The main } \\
\text { basin }\end{array}$ & 6200 & $\begin{array}{l}(-3.70 \mathrm{~m}-4.00 \mathrm{~m}) \\
\text { This part has suffered a loss } \\
\text { of biological balance as a } \\
\text { result of the discharge of } \\
\text { liquid industrial waste and } \\
\text { sewage and animal shelters }\end{array}$ & $\begin{array}{l}\text { The maximum depth of } \\
\text { about } 1.20 \mathrm{~m} \text { and is } \\
\text { bordered to the north by } \\
\text { Muharram beq road and is } \\
\text { bordered to the east by the } \\
\text { international road link, to } \\
\text { the south by the desert } \\
\text { road to Cairo }\end{array}$ \\
\hline $\begin{array}{l}\text { 2. North } \\
\text { West basin }\end{array}$ & 3500 & Less than $(-3.60 \mathrm{~m})$ & Water depth of $1.25 \mathrm{~m}$ \\
\hline $\begin{array}{l}\text { 3. Fishing } \\
\text { basin }\end{array}$ & 1000 & $(-3.75 \mathrm{~m})$ & Water depth of $1.35 \mathrm{~m}$ \\
\hline $\begin{array}{l}\text { 4. South } \\
\text { Western } \\
\text { basin }\end{array}$ & 7000 & $\begin{array}{l}\text { A shallow pond with a lot of } \\
\text { reeds and papyrus plants, a } \\
\text { large part of it has been } \\
\text { dried for agrarian reform. }\end{array}$ & Water depth of $0.5 \mathrm{~m}$ \\
\hline
\end{tabular}

\subsection{The water level in the lake}

Currently declining water level in the lake varies from the average sea level rise of about 3 meters. To maintain that level water is pumped from the lake to the sea through the toll stations, pumps, making the average water depth in the lake $2.00 \mathrm{~m} \mathrm{[7].}$

The lake level in the previous periods $(-2.4 \mathrm{~m})$ after the events of angle Abdul Qadir and the collapse of bridges west Nubaria Bank, it was reduced to $(-280 \mathrm{~cm})$, which is below the appropriate level to reach the column suitable to allow for reproducibly fisheries where the water column is up in some areas 30 to $40 \mathrm{~cm}$.

\section{Analytical study}

A critical review of the current built environmental characteristics, stated in section 3 above, in terms of sustainability assessment approaches.

Major consequences to the built environment of Lake Mariout's deformation is attributable many different aspects. They are as follows: 


\subsection{Environmental study of the territory of Mariout}

Currently, the management of the lake is controlled by several authorities. If the lake is to continue to provide the services it currently supports, allow the desired level of economic and urban development, environmental intervention is required to improve the water quality. This entry details the analysis of the current ecological state of Lake Mariout and proposes actions for the integrated environmental management of the lake.

A significant population in the surrounding area rely directly on the lake as a source of income and food, to the extent that the lake suffered from severe environmental degradation, over the past forty years, and as a result of urban growth regulator or random most of the time. Reference is also made to industrial growth, in addition to population growth and extensive violations on this watery entity which led to the deterioration of water quality.

\subsection{The size of the environmental problem facing Lake Mariout}

Currently, the lake area is dominated by vegetation, principally Phragmites Australis and Eichornia crassipes, which, if left unmanaged, impacts upon the fisheries production capability [3], resulting into highly eutrophic water quality with increased pollution sources.

In addition, the environmental problem facing Lake Mariout we can also cite the vast amount of different types of waste drainage (agricultural/chemical and human waste ... etc.) which flows into the lake, the average amount of drainage during the year is 9.09 million cubic meters per day.

- The dumping of industrial waste and industrial discharges without processors;

- The dumping of agricultural drainage water with all its pesticides and fertilizers;

- The dumping of sewage without treatment since 1980 and even 1993;

- The dumping of sewage pretreatment before dropped since 1993 and so far in its waters;

- Landfill some parts of the lake to create roads and housing [6].
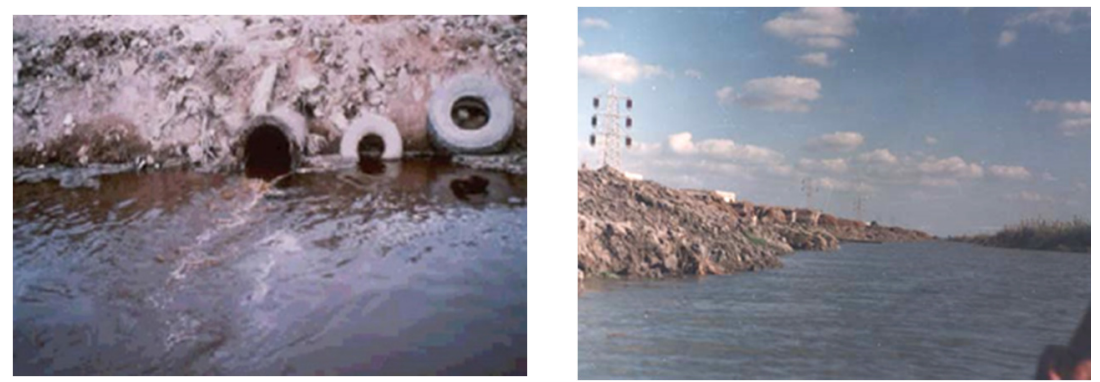

Figure 5: Environmental problem facing Lake Mariout. 
These infringements have led to:

a. Shrinkage of the water area of the lake;

b. Increase organic load due to increased amounts of nitrogen and phosphate salts from various wastewater;

c. Increase of concentration of heavy metals in fish as a result of the adoption of the remains of their food plants that contain a high proportion of those elements;

d. Deterioration of water quality in the main basin, which receives all types of wastewater directly;

e. Request of some individuals to fill and drain parts of the lake.

\subsection{Fish production}

Although the number of sailing boats working on the lake is up to 2458 pound, but the lake area despite low productivity, and reference that impairment is:

- Pollution in the lake drainage from industrial waste sources;

- Untreated sewage;

- Agricultural drainage.

These factors has led to the deterioration of water quality of the lake and the continuation of the decline of fisheries, the following table shows what happened in fish production [8].

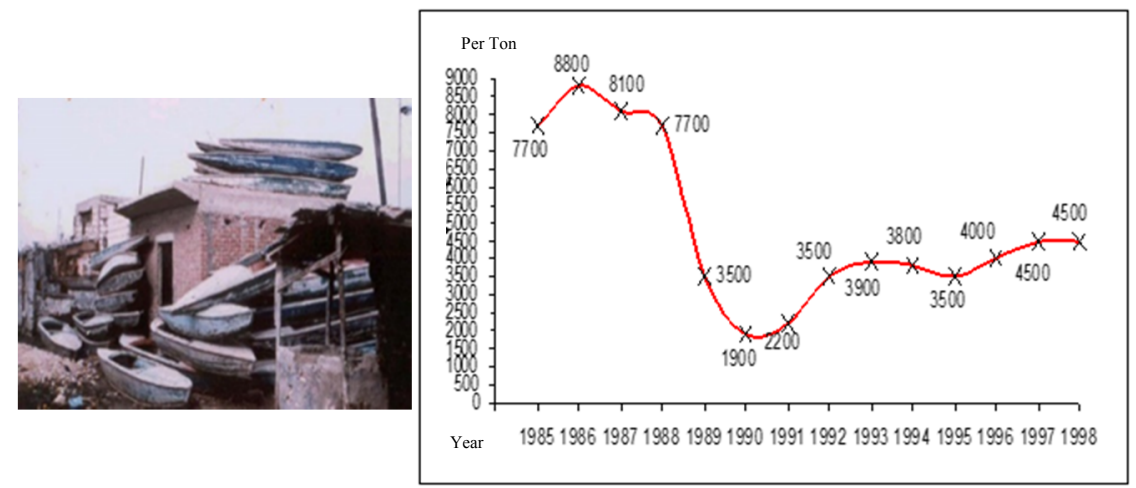

Figure 6: Fish production.

\subsection{Migratory birds}

Living along Lake Mariout basins, especially the main basin, southern basin and western basin lives species of birds feed on insects and plant organisms. There are also some waterfowl existing all around the other basins [8]. 

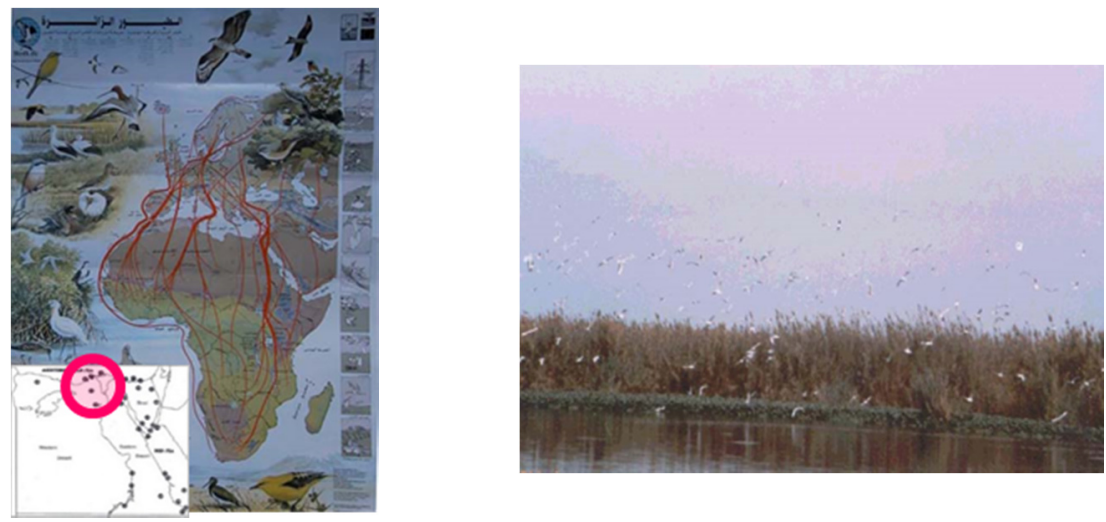

Figure 7: Migratory birds.

\subsection{Land ownership and possession}

There are several ownership and possession claims in the Mariout region, and many cases of property, and forms of tenure. The optimum situation should be that most of these entities need to collaborate on a research base enabling for a governing concept of development and sustainable strategy.

- First: the property is distributed within Mariout region among several government agencies, they are:

State property - The Ministry of Awqaf - Ministry of Culture - Ministry of Defense - Ministry of Agriculture - The Ministry of Irrigation - Ministry of Transportation - The Ministry of Industry - The Ministry of Construction and New Urban Communities - Ministry of Civil Aviation.

- Second: Institutional Entities or Individuals (companies and institutions...)

- Third: there are properties of their respective owners' accidentally fallen rightful within inheritance or by solving endowments, as well as Lands easers.

As a result of the existing controlling process an updated system for legislative issues and empowerments should be adopted for the surrounding properties according to the following criteria:

- Must be interpreted that all government property to preserve the property as a state and is determined on updated maps legally specified.

- Determine the properties of others disputed Land delivered to their owners.

- The areas of services acquired to be determined on registered maps with legislative decisions. (Roads, highways, banks and canals is determined ... etc. In addition to the agglomerations is required for each) as in areas that do not affect the protection of the Lake built environment.

- Determine the water by the entity (updated maps/aerial photographs) to reduce landfill [5]. 


\section{Discussion}

\subsection{The regenerative sustainability paradigm}

The adopted approach of sustainable resources regeneration aims to restore and regenerate the global-social-ecological system through a set of localized design and engineering practices.

While the integration of politicians, planners, economists and businessmen in the process of developing their versions of sustainability interests; another pathway based on a different world wide view representing a manageable system in which humans are separate from nature. This will enable to seeing decision making as a fundamentally interconnected, complex, living and adaptive system that is constantly upgraded.

\subsection{Built environment Sustainable development evaluation}

An explicit 'Evaluation' in terms of a technical-scientific procedure for expressing a judgement, based on values, about the impacts of a policy or of an action on the physical (natural and or built) of Lake Mariout environment, or for assessing the effects of these impacts on the community .

Within this context of sustainable development, the conceptual definition of Sustainable urban regeneration, the urban actors should be classified as follows:

- Political - Leaders of local political parties; environmental spokespersons of local political parties; members of the planning committee(s).

-Economic - Business leaders; investors; land owners; buildings property owners; local; the Chamber of Commerce investments; the Institute of Directors; Managing Directors of utility companies; Managing Directors of transport companies; local authority business and tourism development officers.

- Social - Community stakeholders (fishermen, residents, visitors...);

Education and religious leaders

- Technical - Officers of local authority (communities councils, planning, economic development, transport engineering); professional consultants (environmental, architects, engineers, surveyors, conservationists); technical representatives (housing associations, development companies, construction companies, utility companies, transport companies).

\subsection{Recommendations}

The local political agenda espouses basin-wide sustainability, economic diversification and environmental improvement, with little progress towards attaining these objectives. Optimal Planning at the municipal level with local decision makers recommends the need for the development of a set of indicators that play an important role in guiding plan development, implementation and refinement, as well as acting as a communication tool for the public.

Environmental policy to relate to sustainable development, including management of toxic chemicals; habitat protection and rehabilitation; fish and 
wildlife management; management of greenhouse gases; protection of human health from environmental stressors; and management of invasive species [9].

\section{Conclusion}

This distinction of decision making framework envisaging various factors within the context of Lake Mariout urban sustainability relevant to the way we see, know, act, live and exists. A distinctive attribute should be binding the relationship between subject's urban actors, planners and stakeholders from one side and of the Lake Mariout built environment from the other.

A deeper explanation of this theory is provided in assessment of Mariout Lake surroundings, with the aim of highlighting the possible opportunities to guide a more efficient decision making for existing problems. The objective of development in this process is to create a sustainable future where people can live in mutually supportive symbiosis with their social and biophysical environment including the enhancement of the whole ecological system.

Therefore, preserving the quality of the environment as well as quality of life for current and future generations, including the possibility for all stakeholders and concerned citizens to participate in decision making process.

\section{References}

[1] Karen E. et al., Environmental Sustainability in Practice? A Macro-scale Profile of Tourist Accommodation Facilities in Australia's Coastal Zone, Vol. 16, Issue 1, 2008.

[2] Habib A., Sustainable planning model toward reviving Lake Urmia, International Journal of Water Resources Development, 2014.

[3] Lindsay B., Alexandria Lake Mariout: Integrated Environmental Management, 2013.

[4] GOPP - General Authority for Urban Planning The Development Strategy of Egypt, Alexandria region (Alexandria-Buheira-Matrouh) [Report] Cairo: Ministry of Housing, 2008.

[5] Friends of the Environment Association in Alexandria Mariout Lake in Danger [Book]. - Alexandria: El-Delta Press Center, 2000. - Vol. I.

[6] Helmy Shaker, The Comprehensive Strategic Development Plan for Lake Mariout Zone with Emphasis on the Immediate Action Plan [Report]. - 2005.

[7] Nareeman S., Evaluation of Lake Mariout status, First Edition, Built Environment Associates NGO, Alexandria, Egypt 2000.

[8] CEDARE \& European Union WADI project, Sustainable management of coastal fresh water bodies: a socio-economic and environmental analysis to enhance and sustain stakeholders' benefits [Report] - Alexandria, 2006.

[9] Sarah E., Great Lakes environmental indicators and state of the environment reporting: use, needs, and limitations, Local Environment, Vol. 15, Issue 8, 2010 . 